\title{
Lipid Condition and Survival in Shrimp (Pandalus borealis) Larvae
}

\author{
Patrick Ouellet ${ }^{1}$ and Christopher T. Taggart \\ Department of Oceanography, Dalhousie University, Halifax, N.S. B3H 4/1, Canada \\ and Kenneth T. Frank \\ Department of Fisheries and Oceans, Marine Fish Division, Bedford Institute of Oceanography, P.O. Box 1006, Dartmouth, N.S. B2Y 4A2, Canada
}

\begin{abstract}
Ouellet, P., C. T. Taggart, and K. T. Frank. 1992. Lipid condition and survival in shrimp (Pandalus borealis) larvae. Can. J. Fish. Aquat. Sci. 49: 368-378.

Groups of shrimp (Pandalus borealis) larvae were reared under different food concentrations and types to assess changes in condition and survival during development. As expected, rate of growth (wet weight) was highei for larvae fed on 300 Artemia nauplii $\mathrm{L}^{-1}$ (San Francisco strain: $0.0528 \mathrm{mg} \cdot \mathrm{d}^{-1}$; Canada strain: $0.0355 \mathrm{mg} \cdot \mathrm{d}^{-1}$ ) compared with those reared at 150 nauplii. $\mathrm{L}^{-1}$ (San Francisco strain: $0.0211 \mathrm{mg} \cdot \mathrm{d}^{1}$ ), larvae fed Isochrysis cells only, and no food. Shrimp larvae reared without food and larvae fed on Isochrysis cells showed a decreasing trend in wet weight during development and did not survive beyond stage II. The triacylglycerol (TAG) content of larvae accumulated rapidly during the initial phase of intermoult followed by a decline to a minimum coincident with ecdysis. High mortality (average $2.2 \% \cdot \mathrm{d}^{-1}$ ) occurred during the first phases of development (first $25 \mathrm{~d}$ ) for all rations. Differences among experiments in the magnitude of the mortality (from 0.86 to $4.66 \% \cdot \mathrm{d}^{-1}$ ) at the first moult were related to the proportion of larvae in poor TAG condition. The results are consistent with the concept that the TAG condition index can be used to forecast, on a relative basis, differential survival among larval groups.
\end{abstract}

Des groupes de larves de crevette (Pandalus borealis) ont été gardés sous différent types et concentrations de nourriture, afin d'étudier l'évolution de la condition et de la survie au cours du développement. Des différences dans la croissance des larves ont été observées tel que prévues à partir des différences de qualité des diètes. Les plus forts taux de croissance (poids humide) ont été observés pour les larves nourries à une concentration de 300 nauplii $\mathrm{d}^{\prime}$ Artemia $\cdot \mathrm{L}^{-1}$ (souche San Francisco: $0,0528 \mathrm{mg} \cdot \mathrm{d}^{-1}$; souche Canada: $0,0355 \mathrm{mg} \cdot \mathrm{d}^{-1}$ ), relativement aux larves nourries à 150 nauplii. $\mathrm{L}^{-1}$ (souche San Francisco: $0,0211 \mathrm{mg} \cdot \mathrm{d}^{1}{ }^{1}$ ), aux larves nourries d'algues $/ 50-$ chrysis et aux larves gardées sans nourriture. Les larves de crevette gardées sans nourriture et les larves nourries de cellules d'Isochrysis ont montré une décroissance en poids au cours du développement et n'ont pas survécu après la première mue (début du stade-II). Le contenu en triacylglycerol (TAG) des larves montre une rapide accumulation de réserves énergétiques tôt pendant l'intermue, suivie d'une diminution jusqu'à un minimum coincident avec les mues. Des mortalités importantes (moyenne de $2,2 \% \cdot \mathrm{d}^{-1}$ ) sont survenues au cours des premières phases du développement (premier 25 jours) dans chaque diète. Les différences dans l'amplitude des mortalités $\left(0.86\right.$ à $\left.4,66 \% \cdot d^{-1}\right)$ pendant la première mue entre les expériences étaient reliées à la proportion de larves en pauvre condition. Les résultats supportent l'idée qu'un indice de la condition larvaire peut être utiliser pour prédire, sur une base relative, la survie des groupes de larves.

Received September 12, 1990

Accepted August 21, 1991

(JA72I)
Reçu le 12 septembre 1990 Accepté le 21 août 1991
$\mathbf{M}$ uch of the current research on the causes of recruitment variability in marine populations is built on the hypothesis that recruitment is a function of larval abundance and survival. However, several attempts to correlate recruitment indices with environmental variables supposedly influencing survival of larvae have failed, and it has been suggested that year-class strength is not generally correlated with larval abundance (Sissenwine 1984). Reasons for the lack of correlation may be inadequate and inaccurate abundance estimates and/or that the environmental variables used did not directly influence survival of the larval stage. One way to strengthen the correlative approach is to better define the factors of the environment directly accountable for differential survival in larval populations. A second is to adjust the larval abundance

'Permanent address: Ministère des Pêches et des Océans, Institut Maurice-Lamontagne, Ste-Flavie (Québec) G5H 3Z4, Canada. estimates with expectations of differential survival that are based on the condition of the larvae.

Several methods have been proposed to assess condition of larval fish based on morphometric and histological indexes (Shelbourne 1957; Theilacker 1978; O'Connell 1976). However, these methods have the disadvantage of relying on some subjective categories, are time consuming to derive, and can be difficult to use. Ehrlich (1974) criticized the use of a morphometric condition index and proposed the use of elemental chemical composition to assess condition. More recently the determination of total RNA content and the RNA/DNA ratio have been employed to assess the growth of fish larvae in the sea (Buckley 1984; Buckley and Lough 1987; Robinson and Ware 1988). A biochemical condition index based on the energetic (i.e. lipid) content of individual larvae has also been recently proposed (Fraser et al. 1987; Fraser 1989; Hakanson 1989a, 1989b). However, the quantitative relationship between any condition index and survival probability remains to be 
established. If established, a powerful means of improving recruitment studies will be available.

Lipids, and particularly neutral lipids, have been identified as the main energetic reserve for the larvae of many invertebrate marine species (oyster, Holland and Spencer 1973; scallop, Whyte et al. 1987; lobster, Sasaki et al. 1986). The pelagic development of decapod crustacean larvae entails a sequence of moult and intermoult periods during which the feeding regime appears to be the determinant of success (Anger and Dawirs 1981; Gore 1985). In this study, we assessed the condition (lipid content) and survival among groups of shrimp (Pandalus borealis) larvae reared in a variety of feeding regimes. Our objective was to evaluate the possibility that survival and physiological condition can be quantitatively linked in a predictive manner.

As the lipid content of individual shrimp larvae and its relationship to feeding history have not been reported, we designed this initial study with several objectives: (1) to measure the lipid content of individual larvae, (2) to measure changes in lipid content in response to different foods, and (3) to assess the relationship between lipid content and survival. This paper presents results that demonstrate the potential use of variability in larval condition as a predictor of differential survival among larval populations.

\section{Materials and Methods}

\section{Lipids and Larval Development}

A key assumption in our approach is that the pattern of physiological and biochemical changes apparent in crab (Hyas araneus) larvae (Anger and Dawirs 1981; Anger et al. 1989) is applicable to shrimp. Stated briefly, early in the moult cycle, postmoult period, water and minerals are taken up by the larvae. This is followed during the intermoult by the accumulation of organic reserves and tissue growth when food is available. Under ideal conditions, the postmoult and intermoult are assumed to last for approximately one third of the stage duration (Anger and Dawirs 1981). From the time accumulated reserves reach saturation levels (point of reserves saturation (PRS)), moulting hormones ( $\beta$-ecdysone) ensure the completion of the moult cycle (independent of further feeding). These two phases are reflected by changes in the biochemical composition $(\mathrm{C} / \mathrm{N}$ ratio) of the larvae showing lipid (carbon (C)) accumulation during the first part of each moult cycle and protein accumulation (nitrogen $(\mathrm{N})$ ) during the premoult stages (Anger et al. 1989). The results of simple simulation are presented in Appendix 1 to support the assumption.

\section{Feeding Experiments}

Ovigerous female shrimp were obtained from the northern Gulf of St. Lawrence in mid-April 1989 and were transferred to the Aquatron Laboratory at Dalhousie University, Halifax, Nova Scotia (Canada), where they were incubated, in the dark, in a 80 - $\mathrm{L}$ container of recirculating seawater $\left(\sim 4^{\circ} \mathrm{C}\right)$. Hatching began $2 \mathrm{~d}$ later. When a sufficient number of larvae $(>50)$ were observed in the incubator, groups of 50-400 larvae were isolated for use in the various feeding experiments. Actively swimming larvae were collected with a wide-aperture pipette and were transferred to rearing tanks filled with filtered $(15 \mu \mathrm{m})$ seawater. As collections relied on the hatching rate, there were different initial numbers of larvae among the different experiments. The rearing tanks were chilled using Aquatron seawater.

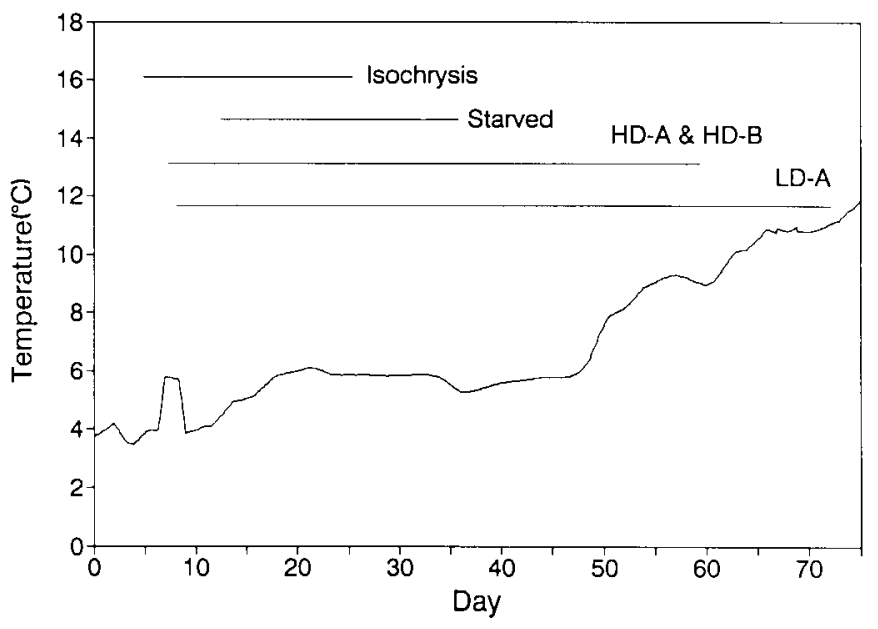

FIG. 1. Hourly average of water temperature for the duration of the rearing. Horizontal bars indicate the relative position of each experiment over the period.

This method maintained the rearing temperature at an average of $5.4^{\circ} \mathrm{C}$ (SD 0.82) during the first $50 \mathrm{~d}$ of the experiment (Fig. 1). As the limited temperature variation was synchronous among all containers, it was not considered a factor in the experimental design.

The choice of foods for the larvae was determined by the previous studies describing successful development of shrimp larvae fed Artemia nauplii alone e. g. P. borealis (Stickney and Perkins 1981; Wienberg 1982; Nunes 1984), Palaemon serratus (Wickins 1972), and Palaemonetes spp. (Knowlton 1974; Freeman 1990). Food of varying quality was purposely selected by using different Artemia strains (Wickins 1972; McConaugha $1985)$ and feeding the larvae the small flagellate Isochrysis spp. (Nunes 1984; Harms and Seeger 1989).

The effect of different foods on larval condition and survival was assayed by feeding two groups of 100 recently hatched ( $<2 \mathrm{~d}$ old) shrimp larvae a ration of Artemia nauplii $\left(300 \cdot \mathrm{L}^{-1} \cdot \mathrm{d}^{-1}\right)$ newly hatched from (a) San Francisco Bay strain cysts (high density A (HD-A)) and (b) Canada strain cysts (high density $\mathrm{B}$ (HD-B)). The larvae were held in 5-L Erlenmyer flasks with a constant air stream to ensure oxygenation and the uniform dispersion of nauplii. The containers were cleaned and the water changed every second day for the duration of the experiment. The static container experiment was completed by providing a group of 50 larvae contained in a 3-L Erlenmyer flask a concentration of the algae Isochrysis spp. $\left(2 \times 10^{4}\right.$ cells $\cdot \mathrm{L}^{-1} \cdot \mathrm{d}^{-1}$ ) and treated as above.

A second treatment involved feeding a group of 400 shrimp larvae in a 40 -L flow-through reservoir 150 nauplii $\cdot \mathrm{L}^{-1} \cdot \mathrm{d}^{-1}$ of the San Francisco strain Artemia. In comparison with the HD-A ration, this treatment served as a low density A (LD-A) ration. Finally, a group of 200 shrimp larvae was held without food (Starved) in a similar flow-through reservoir to serve as control for the biochemical analysis.

A modification of all the nauplii feeding experiments was applied two thirds of the way through the rearing period (day 30 ) by reducing the food ration to one half. This modification was designed to increase the nutritional stress on the larvae during a period of constant survival after the first two moult cycles and to examine the short-term response (lipid content) of the larvae to a change in prey concentration. The ratios were returned to the initial levels after the pseudo-fasting period of 

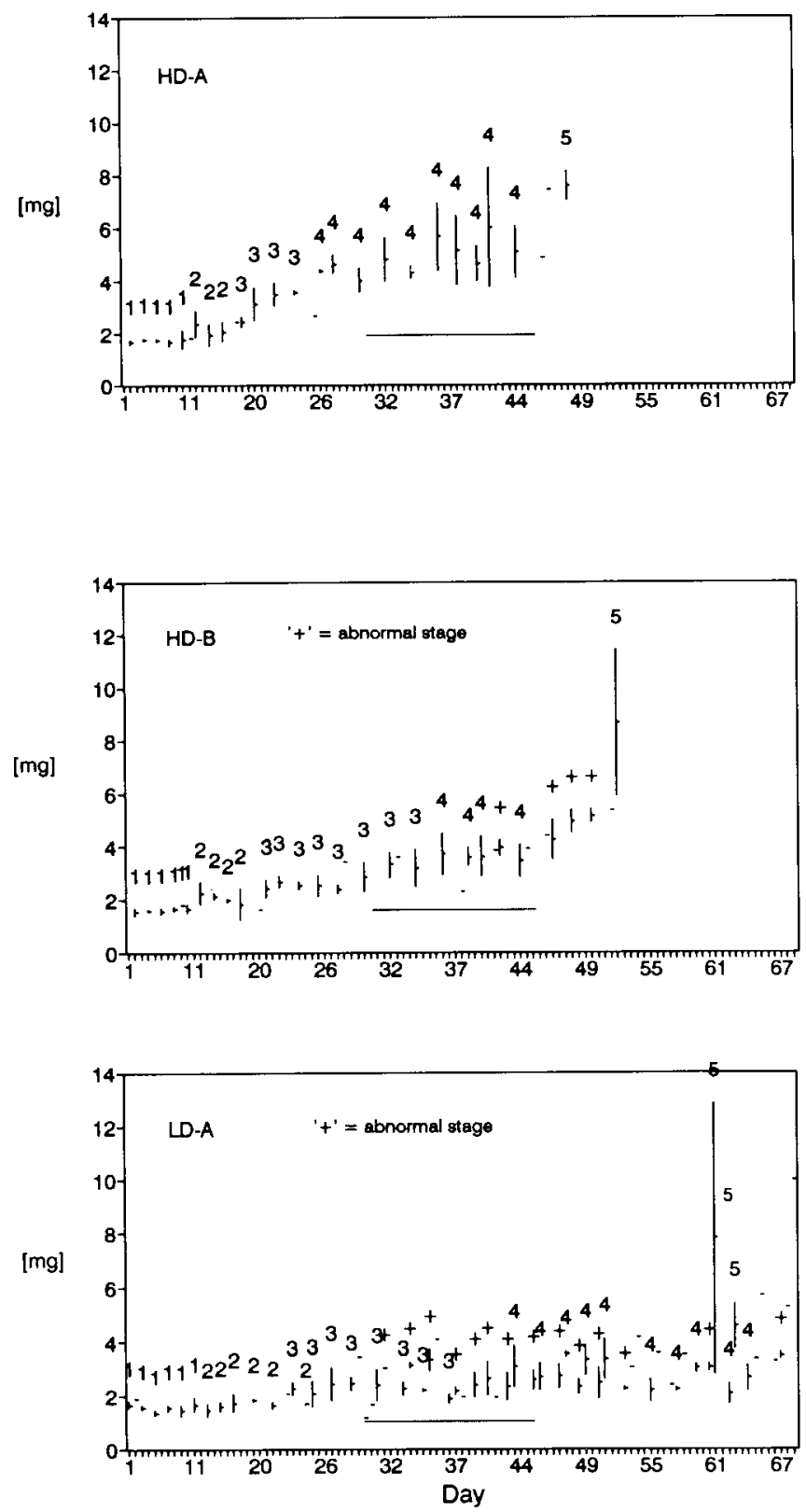

FIG. 2. Average wet weight ( \pm 1 SD) of live shrimp larvae sampled for biochemical analysis from the Artemia-fed groups two strains of Artemia at high density (HD-A, HD-B) and one at low density (LDA)). The numerals and symbols above each data point indicate the developmental stage. The horizontal line represents the period of half food ration.

$15 \mathrm{~d}$ (day 45). The maximum larval density never exceeded 1 larva $.50 \mathrm{~mL}^{-1}$ in any reservoir to minimize the chances of cannibalism (Nunes 1984).

Dead shrimp larvae from each container were counted and preserved each day. Live larvae (three for each of the HD-A, HD-B, and Isochrysis rations and five from the LD-A and Starved larvae) were collected every second day for biochemical analysis. All larvae (dead and live) were staged, measured (total and carapace length), wet-weighed after blotting on absorbent paper, and immediately stored individually in liquid nitrogen. Staging of the larvae was based on Haynes (1979). Atypical stages of development after a given moult were defined as abnormal stages.

\section{Biochemical Analysis}

The extraction procedure for the neutral lipid was based on the protocols of Gardner et al. (1985) and Fraser et al. (1985). No more than two larvae, i.e. for the smallest zoea I, and usually only one was homogenized with a glass pestle in $500 \mu \mathrm{L}$ of solvent (dichloromethane-methanol $(2: 1, \mathrm{v} / \mathrm{v}))$ in an ice bath. The homogenate was rinsed with $250 \mu \mathrm{L}$ of a $\mathrm{KCl}$ solution $(0.88 \%)$ and centrifuged twice at $4000 \mathrm{rpm}$ for $3 \mathrm{~min}$. The lipid fraction was removed after each wash and transferred to a clean tube. A known quantity $(10-20 \mu \mathrm{g})$ of Nonadecane was then added for use as an internal standard. The solvent was evaporated under a nitrogen stream and the lipid was resuspended in 15-20 $\mu \mathrm{L}$ of solvent before the entire sample was spotted on a SIII-Chromarod for quantification using flame ionization detection with a model MK-III IATROSCAN (Iatron, Inc., Japan). The rods were initially developed for $30 \mathrm{~min}$ in hexane - ethyl ether - formic acid (82:2.5:0.045, $\mathrm{v} / \mathrm{v} / \mathrm{v})$ allowing separation of the Nonadecane and the esters. Each rod was secondarily developed for $30 \mathrm{~min}$ in hexane - ethyl ether - formic acid $(55: 29.7: 0.075, \mathrm{v} / \mathrm{v} / \mathrm{v})$ for separation of the triacylglycerol (TAG), free fatty acid (FFA), and sterol constituents. The entire procedure took $\sim 3 \mathrm{~h}$, and $20-30$ larvae could be analyzed by a qualified technician within a regular workday. The quantification of each constituent was based on calibration curves constructed from solutions of standard neutral lipids (Parrish and Ackman 1985; Fraser et al. 1985).

TAG is the primary storage form (as fat) of organic energy in animals, and so the TAG to wet weight ratio ((TAG mg/WW $\mathrm{mg}) \cdot 1000$ )) was used as the index of larval feeding condition. The amount of FFA in a sample is an indicator of the quality of preservation and handling (Christie 1982). A large quantity of FFA indicates that the sample suffered degradation before, during, or after the storage period. Quality control was based on the arbitrary rule that when the quantity of FFA exceeded the quantity of TAG the sample ( $8 \%$ overall) was not included in the analyses.

\section{Data Analysis}

Life table techniques were used to characterize the survival pattern in the larval groups and to compare the results among the different treatments. The method can accommodate censored data, i.e. the removal of live larvae for biochemical analysis which cannot be counted as dead in the survival estimates (Cox and Oakes 1984; Chambers and Leggett 1989). The life table data were used to estimate (1) the Survival function (i.e. the cumulative probability of surviving (event $T$ ) beyond a given time $\mathrm{t}$ ),

$$
\begin{aligned}
& S_{(t)}=\operatorname{Prob}(T>t) \\
& \hat{S}_{(t)}=\prod_{t=0}^{k}\left(1-\frac{d_{t}}{N_{t}}\right)
\end{aligned}
$$

where $d_{t}$ is the number of dead larvae for the interval $k(t, t+$ $\Delta t$ ) and $N_{t}$ is the initial number of live larvae at the beginning of the interval, corrected for larvae removed for the biochemical analysis, and (2) the Hazard function (i.e. the conditional probability of death in a given interval),

$$
h_{(t)}=\lim _{\Delta t>0} \frac{\operatorname{Prob}\{(t<T \leqslant t+\Delta t \mid T>t)\}}{\Delta t}
$$


TABLE 1. Mean total length (TL) and carapace length (CL) (millimetres) and standard deviation for each larval stage and treatment. Values in parentheses represent relative (percent) length increase between moults $(\mathrm{MI}=$ (postmoult $\mathrm{CL}-$ premoult CL)/premoult CL).

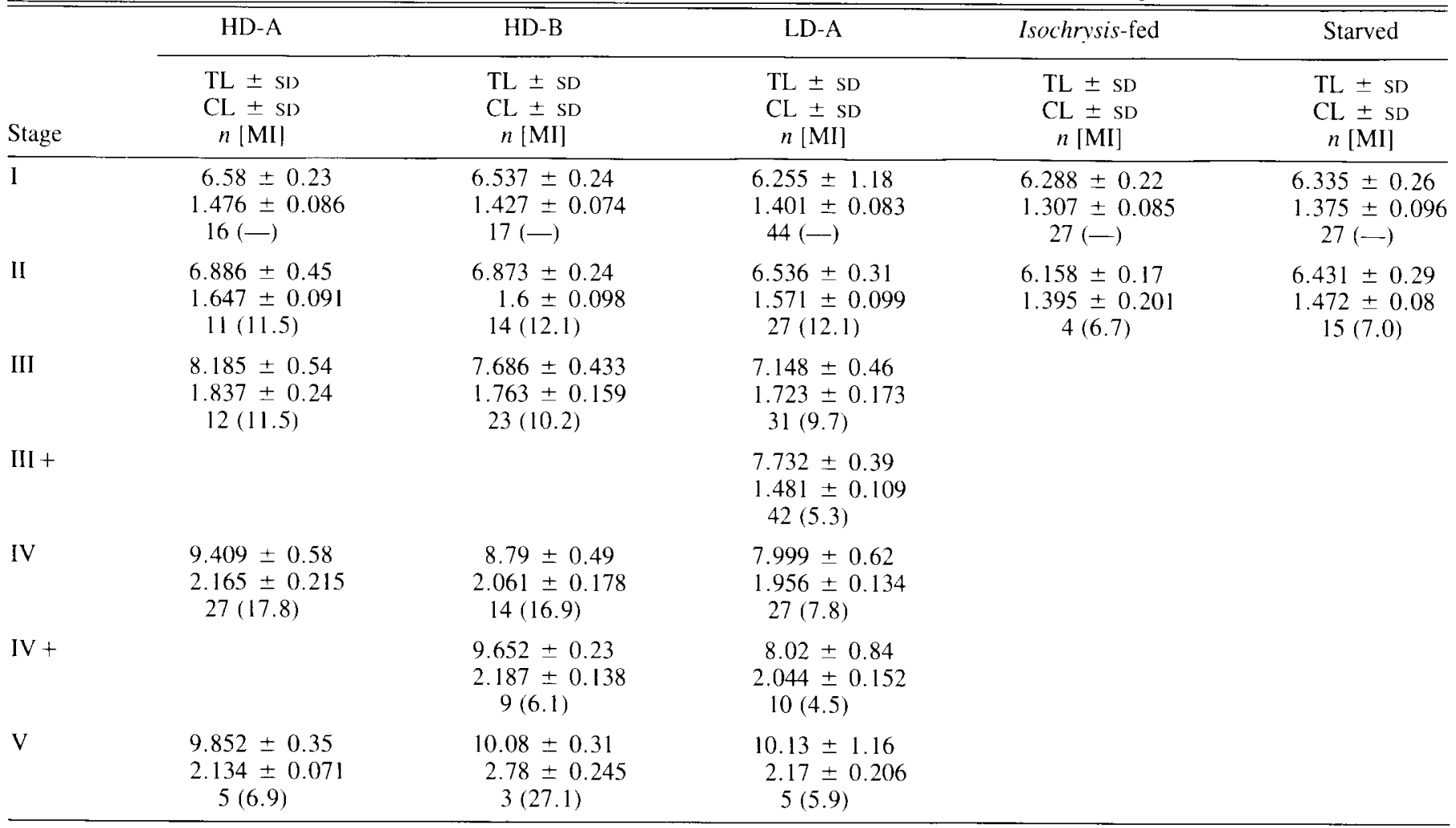

or, following conditional probability theory,

$$
\begin{aligned}
& \operatorname{Prob}\{(t<T \leqslant t+\Delta t)\}=f_{(t)} \cong-\frac{d \hat{S}_{(t)}}{d t} \\
& \hat{h}_{(t)}=\frac{\hat{f}_{(t)}}{\hat{S}_{(t)}}=-\frac{d\left[\ln \hat{S}_{(t)}\right]}{d t} \\
& \hat{H}_{(t)}=-\ln \left(\hat{S}_{(t)}\right) .
\end{aligned}
$$

The two functions are interrelated and the general expression for the Survival function in terms of the Hazard function is $S_{(t)}=\exp \left[-H_{t}\right]$. No attempt was made to fit distribution models to the data. However, the relationship between $\ln \left[-\ln \left(S_{(t)}\right)\right]$, i.e. $\ln \left(H_{t t}\right)$, and $\ln$ (Day) for the periods of high mortality in each experiment was linear and conformed to the Weibull distribution (Lawless 1982), i.e. the hazard function is a power function of time:

$$
S_{(t)}=\exp \left[-\lambda(\text { Day })^{\beta}\right] .
$$

Estimates of the parameters $(\lambda, \beta)$ were obtained by linear regression and were used to compare the distributions among the experiments.

\section{Results}

\section{Larval Growth and Development}

The different feeding conditions were reflected in the marked differences in growth (wet weight) and development (stage) of shrimp larvae (Fig. 2). Limited or insignificant increases in size and length (Table 1) were observed from stage I to stage II zoeae, but different growth rates were observed from stage II to stage $\mathrm{V}$ larvae among the feeding regimes (Table 1; Fig. 2). The rate of growth was significantly higher $(0.0528$ and 0.0355 $\mathrm{mg} \cdot \mathrm{d}^{-1}$ ) for HD-A and HD-B larvae relative to the LD-A larvae $\left(0.0211 \mathrm{mg} \cdot \mathrm{d}^{-1}\right)$. The Isochrysis-fed and Starved larvae did not survive past the first moult (early stage II) and the larvae in both groups showed a decrease in wet weight during development (Fig. 3A).

The larvae that grew faster also developed and moulted more rapidly (Table 2). Development was slower for the larvae on the HD-B ration and abnormal stages were observed before reaching a distinct stage $\mathrm{V}$ (Fig. 2). Development was more variable in larvae reared on the $\mathrm{LD}-\mathrm{A}$ ration. Abnormal stages were observed cooccurring with distinct stage IV and $\mathrm{V}$ larvae (Fig. 2; Table 2). However, despite the relatively slow growth, moulting continued regularly until the end of the experiment. The first moult (I to II) was delayed by 2-3 d in the Isochrysisfed, Starved, and LD-A larvae relative to the HD-A and HD-B larvae (Table 2).

Differences in average wet weight at a given stage were observed between the dead and live larvae within the treatments (Fig. 4). With the exception of the Starved group (where live larvae can not assimilate any food and growth), dead larvae were significantly smaller (by $10-30 \%$ ) in size. The degradation of the biochemical material prevented a comprehensive analysis of the lipid content of the dead shrimp larvae.

\section{Neutral Lipids and Development}

The standardized index of larval condition (TAG wet weight ratio (TAG/WW)) showed considerable variation during larval development (Fig. 3B, and 5). At hatching the index was at or near zero in all treatments. The index fluctuated with no distinct periodicity and never exceeded 0.7 in the Isochrysis-fed and 

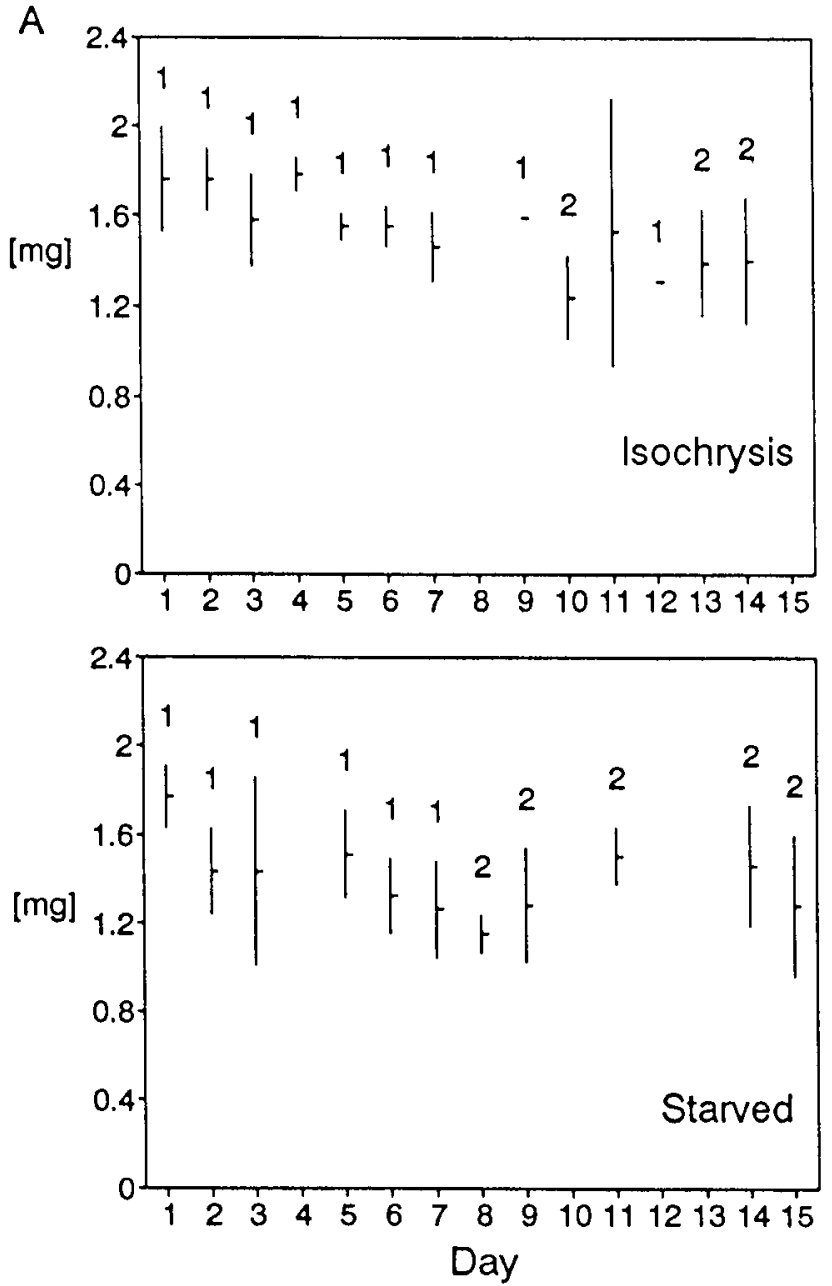

B
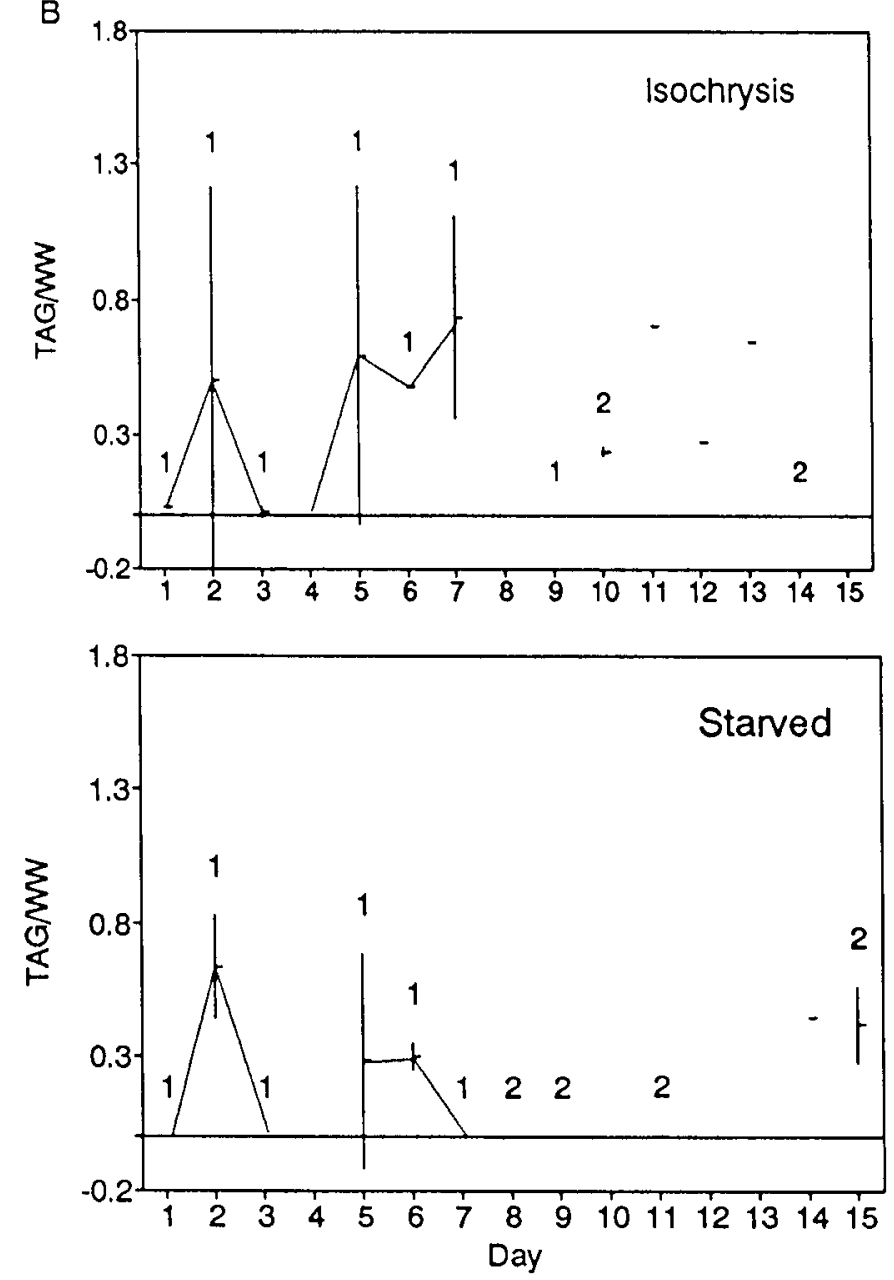

FIG. 3. (A) Average wet weight ( $\pm 1 \mathrm{SD}$ ) of shrimp larvae sampled live for biochemical analysis from the Isochrysis-fed and Starved groups. The numerals and symbols above each data point indicate the development stage. (B) Average TAG/WW ratios ( $\pm 1 \mathrm{SD}$ ) of the shrimp larvae sampled live in the Isochrysis-fed and Starved groups.

Starved groups (Fig. 3B). In contrast, in all the Artemia nauplii groups the index began increasing immediately after hatching, reaching a maximum $3-5 \mathrm{~d}$ later (Fig. 5). The TAG/WW ratio then decreased to a minimum that coincided with moulting. The pattern was observed for the LD-A through the third moult and for the first two moult cycles in HD-B larvae (Fig. 5). In contrast, in the HD-A larvae the condition index reached a maximum $5 \mathrm{~d}$ after hatching, but no minimum coincident with the first moult was observed (Fig. 5). Finally, lower values of the TAG/WW ratios were observed during the period of half-food rations in each treatment (Fig. 5).

The frequency distribution of individual condition (TAG/ WW) reflected the effect of the different rearing conditions on the overall condition of the larval groups (Fig. 6). The estimates were made on individual larvae only. The majority $(>50 \%)$ of Isochrysis-fed and Starved larvae had a very low $(\leqslant 0.2)$ condition index. In comparison, the Artemia-fed groups had a majority ( $\geqslant 70 \%$ ) of stage I and II (live) larvae with an index of $>0.2($ mean $=0.508(\mathrm{CV}=58.3 \%), 0.682$ $(84.2 \%)$, and 0.604 (114.2\%) for HD-A, HD-B, and LD-A, respectively). The proportion of larvae (stages I and II) with a lower index (TAG/WW $\leqslant 0.2$ ) was higher in the LD-A larvae relative to the HD-A and HD-B larvae (fig. 6), but Kolmogo-
rov-Smirnorv tests revealed no significant differences in the frequency distributions between the Artemia-fed groups when tested pairwise $(P>0.05)$.

\section{Survival}

Larval survival for all treatments decreased after $10 \mathrm{~d}$ (first moult) and, not surprisingly, declined more rapidly in the Isochrysis-fed and Starved larval groups (Fig. 7A). After the first moult, survival remained relatively constant in the Artemia-fed groups (HD-A, HD-B), except at $60 \mathrm{~d}$ in the LD-A larvae when survival decreased from 0.6 to 0.2 in a period of $5 \mathrm{~d}$. The event coincided with increasing water temperature, above $8^{\circ} \mathrm{C}$, that could have affected respiratory metabolism and survival. Mortality was not random and was more likely to occur during moulting events (Run test, $0.01<P<0.06$ ). Mortality was especially concentrated during and following $(>10 \mathrm{~d})$ the first moult as shown from the Hazard functions (Fig. 7B). Increasing risk of dying, i.e. higher slope of the cumulative Hazard function, corresponded to the different feeding regimes (Table 3) and were well correlated with the condition indices (proportion of larvae in TAG/WW $\leqslant 0.2$ ) of the larval groups (Fig. 8). 
TABLE 2. Moult frequency and developmental stage duration (days) of shrimp larvae in each treatment. Min. = number of days since the beginning of the experiment for the first observation of the stage; Max. $=$ number of days for completion of the stage (e.g. all larvae have moulted to the next stage); Mean = mean duration of the stage.

\begin{tabular}{|c|c|c|c|c|c|c|}
\hline \multirow[b]{2}{*}{$\begin{array}{l}\text { From stage: } \\
\text { To stage: }\end{array}$} & \multicolumn{6}{|c|}{ Moult sequence } \\
\hline & $\begin{array}{l}\text { I } \\
\text { II }\end{array}$ & $\begin{array}{l}\text { II } \\
\text { III }\end{array}$ & $\begin{array}{c}\text { III } \\
\text { III + }\end{array}$ & $\begin{array}{l}\text { III }(\mathrm{III}+) \\
\text { IV }\end{array}$ & $\begin{array}{l}\text { IV } \\
\text { IV + }\end{array}$ & $\underset{\mathrm{V}}{\mathrm{IV}}(\mathrm{IV}+)$ \\
\hline \multicolumn{7}{|l|}{ HD-A } \\
\hline Min. & 10 & 18 & & 25 & & 46 \\
\hline Max. & 12 & 20 & & 28 & & END \\
\hline Mean & 11 & 8 & & 7.5 & & 20 \\
\hline \multicolumn{7}{|l|}{ HD-B } \\
\hline Min. & 10 & 19 & & 28 & 36 & 45 \\
\hline Max. & 13 & 22 & & 34 & 38 & END \\
\hline Mean & 11.5 & 9 & & 10.5 & 6 & 11.5 \\
\hline \multicolumn{7}{|l|}{ LD-A } \\
\hline Min. & 13 & 22 & 30 & 43 & 61 & 65 \\
\hline Max. & 16 & 27 & 35 & 55 & END & END \\
\hline Mean & 14.5 & 10 & 8 & 16.5 & 15 & 5 \\
\hline \multicolumn{7}{|l|}{ Isochrysis-fed } \\
\hline Min. & 13 & & & & & \\
\hline Max. & 16 & & & & & \\
\hline Mean & 14.5 & & & & & \\
\hline \multicolumn{7}{|l|}{ Starved } \\
\hline Min. & 12 & & & & & \\
\hline Max. & 14 & & & & & \\
\hline Mean & 13 & & & & & \\
\hline
\end{tabular}

\section{Discussion}

Our results support the proposed use of a relatively easily determined biochemical condition index as an indicator of survival potential among various larval groups. These are encouraging results given the difficulty in the past of establishing the full utility of trophic factors in recruitment studies (Rothschild et al. 1989).

\section{Larval Growth and Development}

The results are consistent with what is known about the pattern and sources of variation in decapod larval development (Knowlton 1974; McConaugha 1985). The different growth efficiency and development patterns observed in the larvae fed on Artemia nauplii rations illustrate the sensitivity of larval shrimp growth and condition to the food resources. The occurrence of abnormal stages, and the coincidence of moulting immediately following periods of pseudo-fasting (see Fig. 2), demonstrates a rapid adjustment of the larval growth pattern to changes in food quantity. The most dramatic influence of the feeding condition was observed in larvae fed the LD-A ration. These larvae displayed very limited or no growth during development, indicating that assimilated organic energy was directed toward moulting and morphogenesis at the expense of growth. However, the growth restraint was not without cost given the significantly smaller size of the dead larvae that had presumably failed to secure the minimal reserves necessary for continued survival and development.

The poor growth performance of the larvae with access only to Isochrysis cells corroborates earlier reports of the inadequacy of those small flagellate cells to support growth and normal development of the larvae (Nunes 1984). Survival of starved shrimp larvae through a first moult has been reported by Stick-
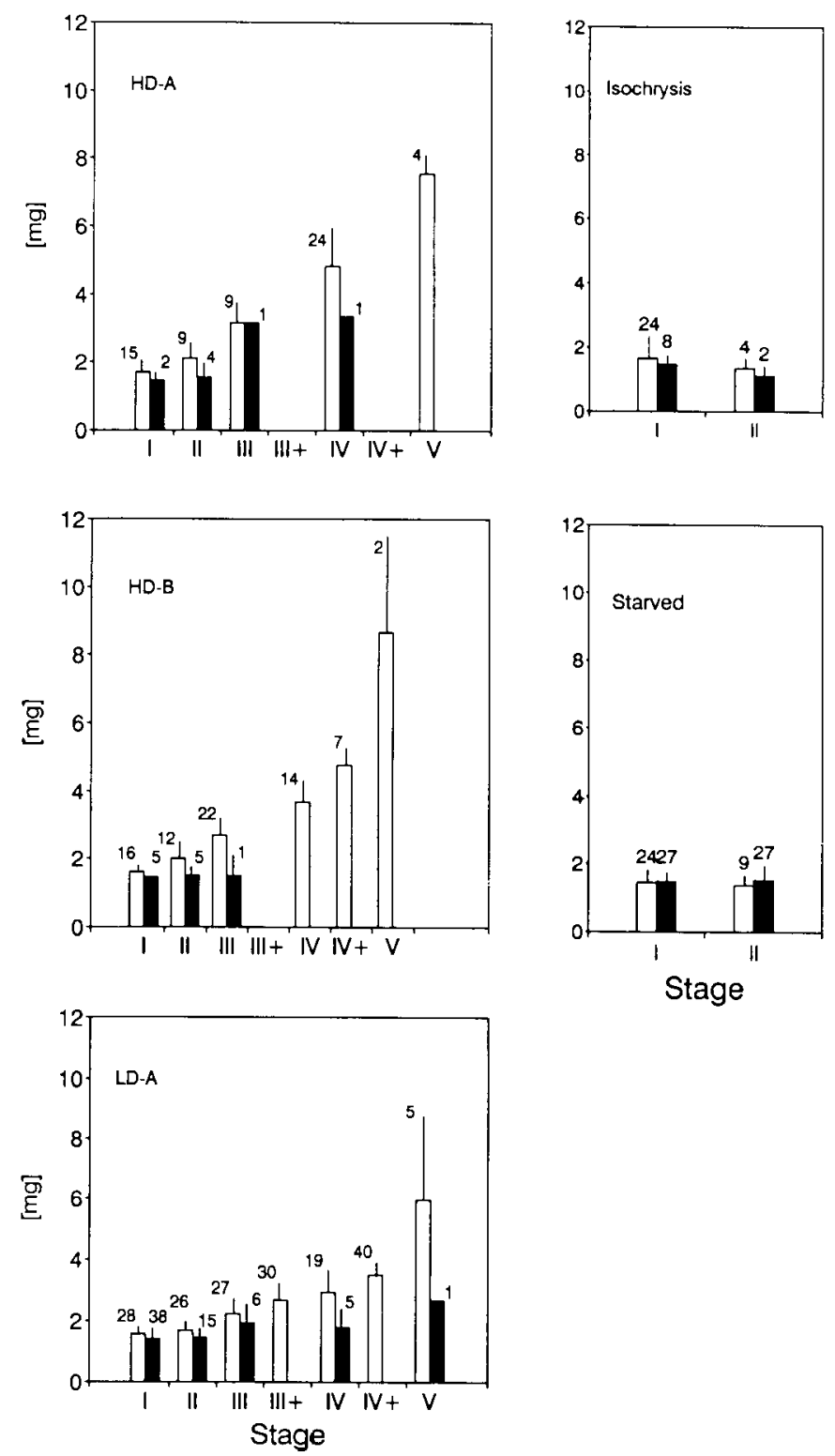

FIG. 4. Mean wet weight per stage for live (open bars) and dead (solid bars) larvae for each feeding treatment. Vertical lines represent 1 SD above the mean and the numerals indicate the number of observations for each group.

ney and Perkins (1981) whereas Wienberg (1982) reported that starved larvae (kept in purified water) were all dead within $9 \mathrm{~d}$ and did not moult. The fact that starved larvae managed to live through the first moult in our experiment may be attributed to the relatively coarse filtering $(15 \mu \mathrm{m})$ of the source water and the ability of larvae to absorb energy from microscopic or dissolved organic matter. We suggest that the same explanation applies to the result of Stickney and Perkins (1981) who used 25 - $\mu \mathrm{m}$-filtered seawater.

Our results must be interpreted with a clear understanding that they are based on artificial diets and rearing conditions that may cause unnatural stress to the larvae. However, the objective of the research was not to study the effect of foods on shrimp larvae development per se. By using feeding conditions of varying quality (well documented in the works cited above) to induce variability in the condition of various shrimp larval groups, it was possible to develop a quantitative index that 

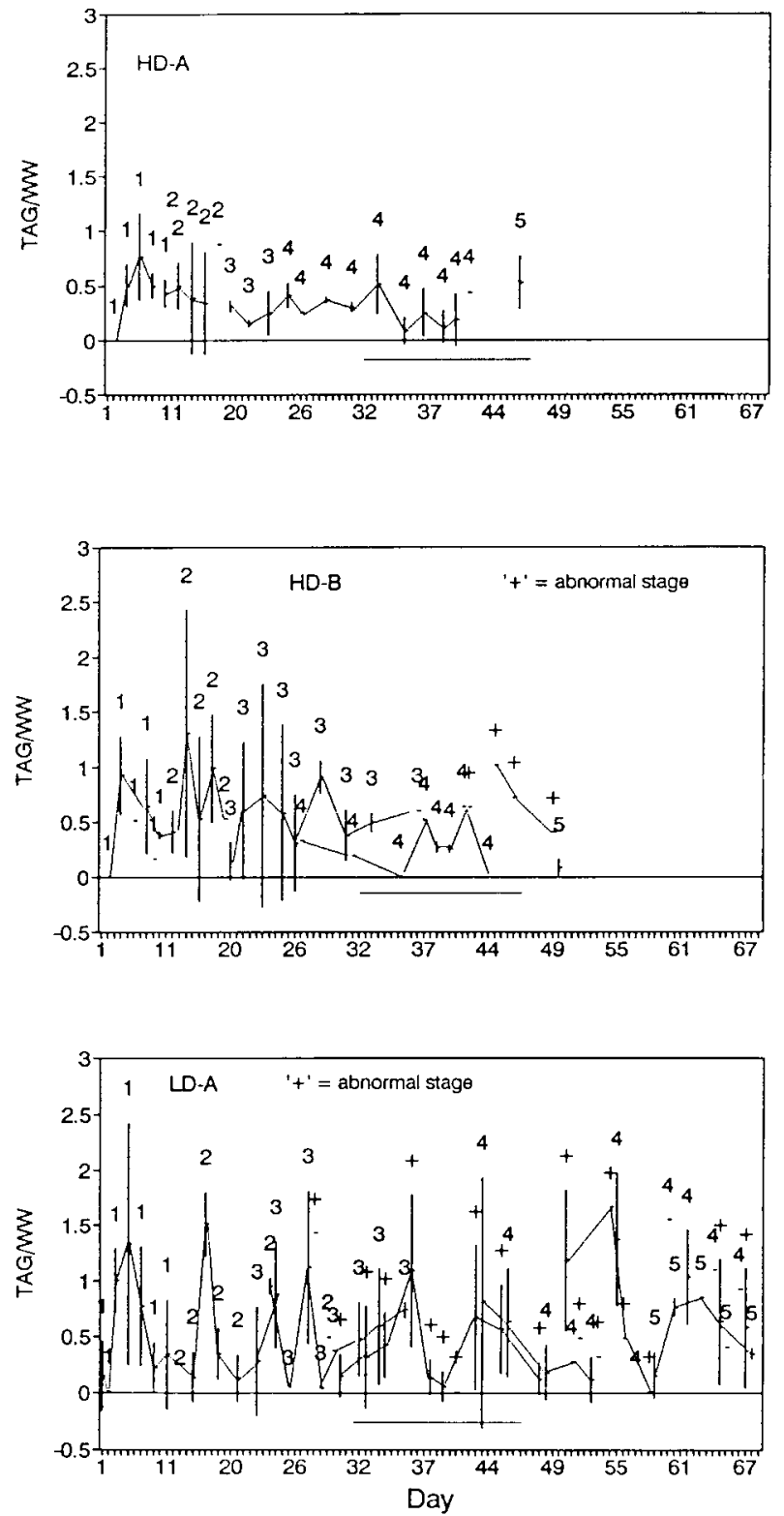

FIG. 5. Average TAG/WW ratios ( $\pm 1 \mathrm{SD}$ ) of live shrimp larvae sampled in the Artemia diet treatments. The numerals and symbols above each data point indicate the larval stage. The curves track a normal (stages I through V) larval development sequence. The horizontal line indicates the duration of the half food ration.

linked larval condition and survival. Although not ideal, the feeding regimes selected are often used for rearing shrimp larvae under laboratory conditions. The quality of various Artemia strains used as decapod larvae food is judged, in part, on the relative proportion of long-chain polyunsaturated fatty acid $(20: 5 \omega 3)$. In this respect the San Francisco strain (HD-A) exceeds the Canada strain (HD-B) by about $30 \%$ (McConaugha 1985 , p. 134), implying that the former represents better food for the larvae. Larval growth rates were consistent with this assessment. Densities of 300 and 150 nauplii $\cdot \mathrm{L}^{-1} \cdot \mathrm{d}{ }^{1}$ have been judged as adequate and marginal concentrations, respectively, in previous attempts to rear $P$. borealis larvae (Nunes 1984 , although phytoplankton at $1 \times 10^{4}$ to $3 \times 10^{4}$ cells $\cdot \mathrm{L}^{-1}$ was also included). Previous works on the feeding response of $P$. borealis larvae indicated that, under laboratory conditions,
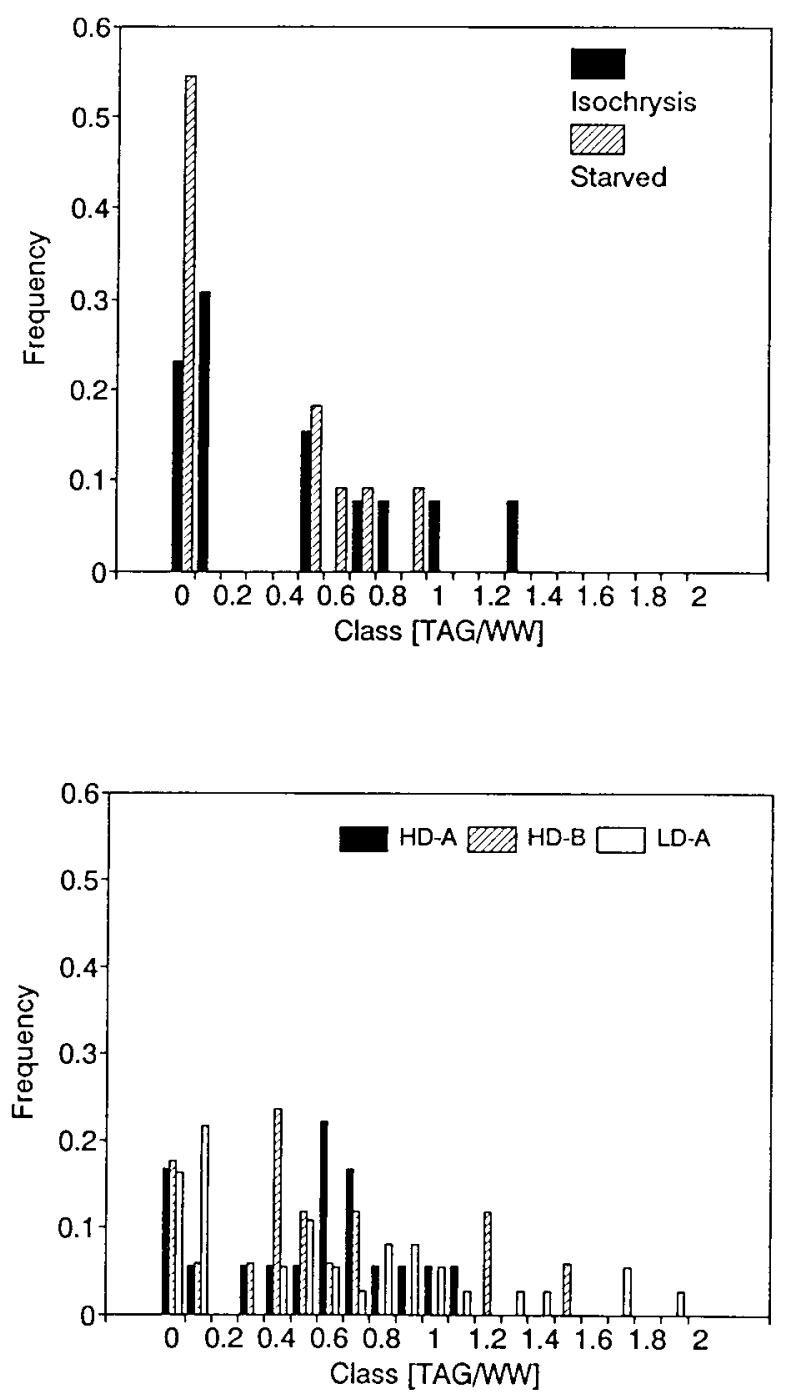

FIG. 6. Frequency (relative) distributions of individual TAG/WW ratios for all live larvae in the Isochrysis-fed and Starved treatments (top panel) and for live stage I and II larvae in the Artemia diet treatments (bottom panel).

prey (copepodite, and copepod nauplii) densities of $80 \cdot \mathrm{L}^{-1}$ were necessary for each larva to capture at least one prey item per day (Paul et al. 1979). The minimum respiratory metabolic requirement of stage $\mathrm{I} P$. borealis larvae was estimated at 0.068 $\mathrm{cal} \cdot$ ind $^{-1}$ at $6^{\circ} \mathrm{C}$, or about 8 times the estimated calorie content $\left(0.0083 \mathrm{cal}^{- \text {ind }^{-1}}\right.$ ) of 1-d-old Artemia salina nauplii (Paul and Nunes 1983). Hence, high prey concentrations are necessary to insure that each shrimp larva can assimilate sufficient organic energy for survival and growth. Furthermore, as the same foods were added each day for the duration of the experiment the number of prey available to the larvae increased and paralleled the increasing metabolic demands of the larvae. There was no evidence of cannibalism in our experiment and the removal of the dead larvae minimized the possibility of necrophagy in the containers. We therefore conclude that the reuslts can provide a valuable method for identifying trophic effects on condition variation in shrimp larvae.

\section{Lipid Content and Survival}

The ecdysis cycle in shrimp larvae can be dsecribed as (a) postmoult (or posthatch for stage I zoea), (b) intermoult, (c) 


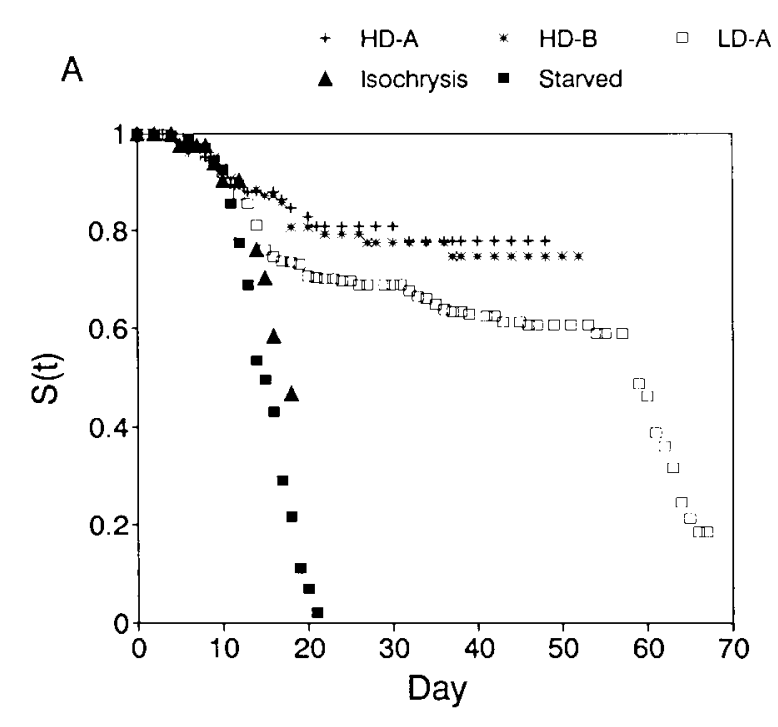

B

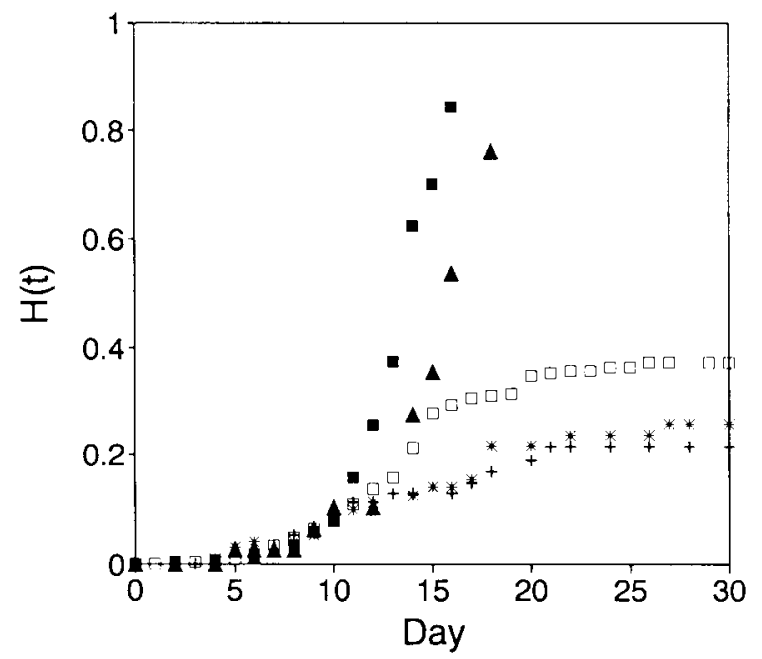

FIG. 7. (A) Survival function $\left(S_{(t)}\right)$ of each larval group for the duration of the experiment and (B) the corresponding cumulative Hazard function $\left(H_{t \prime}\right)$ for the first 30 -d of each treatment.

TABLE 3. Parameters estimated for the relationship between the Hazard function $\left(\ln \left(H_{t}\right)\right)$ and time $(\ln ($ Day $))$ for the first two moults (days 5 $25)$ in each experiment. The time axis $(\ln ($ Day)) was lagged by $5 \mathrm{~d}$ in order to avoid the indetermination in $\ln \left(H_{t}\right)$ when $H_{t}=0$, i.e. no mortalities.

\begin{tabular}{lclcc}
\hline \hline & & $\begin{array}{c}\text { Slope }(\beta) \\
(\mathrm{SE})\end{array}$ & $\begin{array}{c}\text { Intercept } \\
-\ln (\lambda)\end{array}$ & $R^{2}$ \\
\hline HD-A & 16 & $\begin{array}{l}1.747 \\
(0.179)\end{array}$ & -6.798 & 0.871 \\
HD-B & 15 & $\begin{array}{l}1.439 \\
(0.084)\end{array}$ & -5.886 & 0.956 \\
LD-A & 20 & $\begin{array}{l}2.27 \\
(0.116)\end{array}$ & -7.812 & 0.955 \\
Isochrysis-fed & 11 & $\begin{array}{l}2.93 \\
(0.307)\end{array}$ & -9.055 & 0.91 \\
Starved & 17 & $\begin{array}{l}3.342 \\
(0.261)\end{array}$ & -9.508 & 0.916 \\
& & & & \\
\hline
\end{tabular}

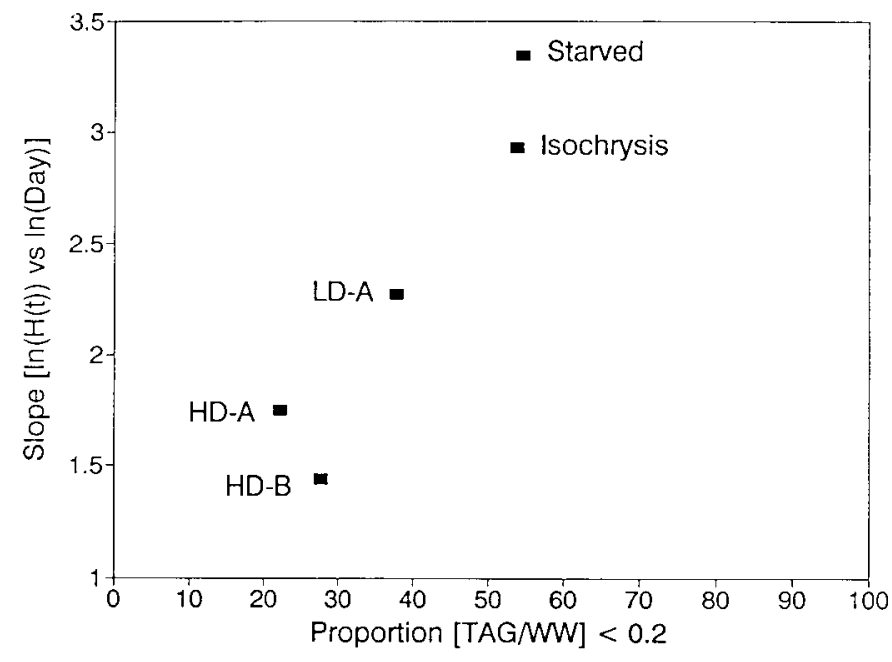

FIG. 8. Relationship between the risk of death (slope of $\ln \left(H_{i t}\right)$ vs. $\ln ($ Day)) and the relative proportions of larvae in poor condition in each feeding treatment.

premoult, and (d) the ecdysis periods (Anger and Dawirs 1981; Gore 1985). The minimal feeding time to reach the threshold in organic reserves and to initiate the premoult independently of further food supply is defined as the reserve saturation point (RSP) (Anger and Dawirs 1981). The same authors also defined the maximum time allowed for accumulation of reserves before the initiation of the premoult phase as the point of nonreturn (PNR). If the reserves threshold has not been reached at the PNR the larva may not survive ecdysis or may not be able to initiate the next postmoult phase, a phenomenon analogous to the "point of nonreturn" described for fish larvae (Blaxter 1969).

In all feeding conditions, the absolute amount of TAG per larvae was low, indicating the priority of development and growth over the accumulation of reserves early in development. However, our results present evidence of a pattern in the management of organic reserves similar to that described by Anger and Dawirs (1981) for Hyas spp. larvae. The larvae appeared depleted of TAG reserves at hatching, but within days $(<5)$ the TAG increased to a maximum, indicative of immediate feeding after hatching. The absence of a well-defined cyclic pattern in the TAG/WW ratio in the HD-A larvae can be interpreted as evidence of the independence of moulting success on TAG reserves. However, under adequate feeding conditions the RSP can amount to only $30 \%$ of the intermoult period (Anger and Dawirs 1981), or only $3 \mathrm{~d}$ posthatch in the HD-A larvae (first moult after $10 \mathrm{~d}, 30 \%$ of $10=3 \mathrm{~d}$ ). Thus, sampling every second day for biochemical analysis may have biased the data and prevented the detection of a clear pattern. Conversely, the variation can be explained by assuming that the food ration (and quality) in the HD-A experiment was adequate to permit minimal growth, development, and successful moulting, i.e. the HD-A larvae were less dependent on the internal storage of organic resources. This is supported by the observation of higher TAG/WW values and cyclic patterns during the first two moults in the slower growing/developing larvae of the HD-B and $L D-A$ regimes. The absence of a clear pattern after the third cycles would result from asynchronous development among larvae, as the mixing of various development stages suggests.

The most significant result of the experiment is the relationship observed between the general condition of the larval groups 
(i.e. proportion of larvae in poor TAG condition) and the risk of death (slope of the Hazard function) during the early moult periods. The simplest explanation is that insufficient organic energy, due to low TAG, results in larval death at moult. Other lipid classes (such as fatty acid or sterol esters and hydrocarbons) were rarely present or only in trace amount.

The prolonged intermoult (the extension of the RSP point) in the LD-A larvae also has the indirect effect of increasing the probability of observing larvae with relatively low TAG content and larvae that cannot secure the minimal energy required by the time of the PNR. This is also the case for the Isochrysisfed and the Starved larvae. The effect is demonstrated by the frequency distributions of the individual condition indices (TAG/WW). The distributions are less variable in the HD-A and HD-B larvae than for larvae in LD-A, which also present a higher proportion of larvae in lower classes and must be recognized as a less favourable ration. The fact that we did not find significant differences in the frequency distributions of the groups (Kolmogorov-Smirnorv tests) does not invalidate the relationship. In fact the results of the tests are not surprising given the lower number of observations $(n=17,18$, and 24 for HD-A, HD-B, and LD-A, respectively), i.e. degrees of freedom for the test. A similiar approach, i.e. modification of the frequency distributions, was also proposed to evaluate changes in the physiological condition (i.e. lipid content) of individual larvae of the bivalve Bankia gouldi (Gallager and Mann 1986).

Overall, our results support the suggestion that the relative condition index among cohorts leads to useful estimates of survival probability and provides a possible method to compensate for the shortcomings of mortality estimates based strictly on larval abundance values (Taggart and Leggett 1987; Taggart and Frank 1990).

\section{Acknowledgements}

We thank Drs. C. C. Parrish, A. J. Fraser, and R. G. Ackman for their advice and comments on the protocol and the biochemical analysis and Katherine Barrett and Walter Hingley for their assistance in the rearing of the larvae and in the laboratory analyses. We are gratefu? to three anonymous reviewers whose critical input led to substantial improvements in our analysis and interpretations.

\section{References}

ANGER, K., AND R. R. DAWIRS. 1981. Influence of starvation on the larval development of Hyas araneus (Decapoda, Majidae). Hegol. Meeresunters. 34: 287-311

Anger, K., J. Harms, C. Püschel, and B. Seeger. 1989. Physiological and biochemical changes during the larval development of a brachyuran crab reared under constant conditions in the laboratory. Helgol. Meeresunters 43: $225-244$

Blaxter, J. H. S. 1969. Development of eggs and larvae, p. 177-252. In W. S. Hoar and D. J. Randall [ed.] Fish physiology. Vol. III. Academic Press, New York, NY.

Buckely, L. J. 1984. RNA-DNA ratio: an index of larval fish growth in the sea. Mar. Biol. 80: 291-298.

BUCKELY, L. J., AND R. G. LOUGH. 1987. Recent growth, biochemical composition, and prey field of larval haddock (Melanogrammus aeglefinus) and Atlantic cod (Gadus morhua) on Georges Bank. Can. J. Fish. Aquat. Sci. 44: 14-25

Chambers, S. R. C., AND W. C. LegGett. 1989. Event analysis applied to timing in marine fish ontogeny. Can. J. Fish. Aquat. Sci. 46: 1633-1641.

CHRIsTIE, W. W. 1982. Lipid analysis: isolation, separation, identification and structural analysis of lipids. 2nd ed. Pergamon Press, Oxford. 197 p.

COX, D. R., AND D. OAKES. 1984. Analysis of survival data - monographs on statistics and applied probability. Chapman and Hall, New York, NY. 201 p.
EHRLICH, K. F. 1974. Chemical changes during growth and starvation of larval Pleuronectes platessa. Mar. Biol. 24: 39-48.

FRASER, A. J. 1989. Triacylglycerol content as a condition index for fish, bivalve, and crustacean larvae. Can. J. Fish. Aquat. Sci. 46: 1868-1873.

Fraser, A. J., J. R. Sargent, J. C. Gamble, and P. Maclachlan. 1987. Lipid class and fatty acid composition as indicators of the nutritional condition of larval Atlantic herring. Trans. Am. Fish. Soc. Symp. 2: 129 143.

Fraser, A. J., D. R. Tocher, and J. R. Sargent. 1985. Thin-layer chromatography - flame ionization detection and the quantification of marine neutral lipids and phospholipids. J. Exp. Mar. Biol. Ecol. 88: 91-99.

FreEMAN, J. A. 1990. Molt increment, molt cycle duration, and tissue growth in Palaemonetes pugio Holthuis larvae. J. Exp. Mar. Biol. Ecol. 143:4761

Gallager, S. M., and R. MAnN. 1986. Individual variability in lipid content of bivalve larvae quantified histochemically by absorption photometry J. Plankton Res. 8(5): 927-937.

Gardner, W. S., W. A. Frez, E. A. Cichocki, and C. C. Parrish. 1985 Micromethod for lipids in aquatic invertebrates. Limnol. Oceanogr. 30: 1099-1105.

GORE, H. R. 1985. Molting and growth in decapod larvae, p. 1-65. In A. M. Wenner [ed.] Crustacean issues 2. Larval growth. A. A. Balkema, Rotterdam, The Netherlands

HaKanson, J. L. 1989a. Analysis of lipid components for determining the condition of anchovy larvae, Engraulis mordax. Mar. Biol. 102: 143151 .

1989b. Condition of larval anchovy (Engraulis mordax) in the southern California Bight, as measured through lipid analysis. Mar. Biol. 102: $153-159$

Harms, J., And B. SEEger. 1989. Larval development and survival in seven decapod species (Crustacea) in relation to laboratory diet. J. Exp. Mar. Biol. Ecol. 133: 129-139.

HAYNES, E. 1979. Description of larvae of the northern shrimp, Pandalus borealis, reared in situ in Kachemak Bay, Alaska. Fish. Bull. U.S. 77: $157-173$.

Holland, D. L., And B. E. Spencer. 1973. Biochemical changes in fed and starved oyster, Ostrea edulis L. during larval development, metamorphosis and early spat growth. J. Mar. Biol. Assoc. U.K. 53: 287-298.

KNOWLTON, R. E. 1974. Larval development processes and controlling factors in decapod Crustacea, with emphasis on Caridea. Thalassia Jugosl. 10(1/2): 138-158.

LAWLESS, J. F. 1982. Statistical models and methods for lifetime data. John Wiley \& Sons, New York, NY.

McConaugha, J. R. 1985. Nutrition and larval growth, p. 127-154. In A. M. Wenner [ed.] Crustacean issues 2. Larval growth. A. A. Balkema Rotterdam, The Netherlands.

NunEs, P. 1984. Reproductive and larval biology of northern shrimp, Pandalus borealis Kroyer, in relation to temperature. Ph.D. thesis, University of Alaska, Fairbanks, AK.

O'ConNelL, C. P. 1976. Histological criteria for diagnosing the starving condition in early post yolk sac larvae of the northern anchovy, Engraulis mordax Girard. J. Exp. Mar. Biol. Ecol. 25: 285-312.

PARrish, C. C., AND R. G. ACKMAN. 1985. Calibration of the Iatroscan-Chromarod system for marine lipid class analyses. Lipids 20: 521-530.

PAul, A. J., AND P. Nenes. 1983. Temperature modification of respiratory metabolism and caloric intake of Pandalus borealis (Kroyer) first zoeae. J. Exp. Mar. Biol. Ecol. 66: 163-168.

Paul, A. J., J. M. Paul, P. A. Shoemaker, and H. M. Feder. 1979. Prey concentrations and feeding response in laboratory-reared stage-one zoea of king crab, snow crab, and pink shrimp. Trans. Am. Fish. Soc. 108 $440-443$.

Robinson, S. M. C., AND D. W WARE. 1988. Ontogenetic development of growth rates in larval Pacific herring, Clupea harengus pallasi, measured with RNA-DNA ratios in the strait of Georgia, British Columbia. Can. J. Fish. Aquat. Sci. 45: 1422-1429.

Rothschild, B. J., T. R. Osborn, T. D. Dickey, and D. M. Farmer. 1989 The physical basis for recruitment variability in fish populations. J. Cons Int. Explor. Mer 45: 136-145.

SAS. 1988. SAS/STAT ${ }^{\mathrm{TM}}$ user's guide, release 6.03. SAS Institute Inc., Cary $\mathrm{NC}$

Sasaki, G. C., J. M. Capuzzo, and P. Biesiot. 1986. Nutritional and bioenergetic considerations in the development of the American lobster Homarus americanus. Can. J. Fish. Aquat. Sci. 43: 2311-2319.

Shelbourne, J. E. 1957. The feeding and condition of plaice larvae in good and bad plankton patches. J. Mar. Biol. Assoc. U.K. 36: 539-552. 
SISSENWINE, M. P. 1984. Why do fish populations vary?, p. 59-94. In R. M. May [ed.] Exploitation of marine communities. Dahlem Konferenzen, Spinger-Verlag, Berlin.

Stickney, A. P., And H. C. Perkins. 1981. Observations on the food of the larvae of the northern shrimp, Pandalus borealis Kröyer (Decapoda, Caridea). Crustaceana 40: $36-49$.

Taggart, C. T., AND K. T. Frank. 1990. Perspectives on larval fish ecology and recruitment processes; probing the scale of relationships, chap. 12. In K. Sherman, L. M. Alexander, and B. D. Gold [ed.] Large marine ecosystems: patterns, processes, and yields. AAAS Selected Symposium, April 1989.

Taggart, C. T., AND W. C. LegGert. 1987. Short-term mortality in postemergent larval capelin Mallotus villosus. I. Analysis of multiple in situ estimates. Mar. Ecol. Prog. Ser. 41: 205-217.

THEILACKER, G. H. 1978. Effect of starvation on the histological and morphological characteristics of jack mackerel, Trachurus symmetricus, larvae. Fish. Bull. U.S. 76: 403-414.

Whyte, J. N. C., N. Bolrne, ANd C. A. Hodgson. 1987. Assessment of biochemical composition and energy reserves in larvae of the scallop Patinopecten yessoensis. J. Exp. Mar. Biol. Ecol. 113: 113-124.

WICKINS, J. F. 1972. The food value of brine shrimp, Artemia salina $\mathrm{L}$., to larvae of the prawn, Palaemon serratus Pennant. J. Exp. Mar. Biol. Ecol. 10: $151-170$.

WIENBERG, R. 1982. Studies on the influence of temperature, salinity, light, and feeding rate on laboratory reared larvae of deep sea shrimp, Pandalus borealis Kröyer 1838. Meeresforschung 29: 136-153.

\section{Appendix 1}

An empirical model for the intermoult TAG cycle was prepared using the Anger et al. (1989, fig. 4, p. 235) $\mathrm{C} / \mathrm{N}$ ratio data for crab ( $H$. araneus) larvae. The changes in $\mathrm{C} / \mathrm{N}$ ratios over time were interpreted as indicative of lipid accumulation during the first part of the cycle (increasing $\mathrm{C} / \mathrm{N}$ ) with a shift to relative higher protein accumulation (declining $\mathrm{C} / \mathrm{N}$ ) at the premoult stages (Anger et al. 1989).

A simple data set was created by using the median of the daily values (scaled between 0 and 1) for zoea I larvae. The relationship was best described by an exponential model:

$$
\mathrm{TAG}=\alpha\left[D-\left(1 / D_{\mathrm{tg}}\right)\right] \exp \left[-\beta\left(D^{2} / D_{\max }\right)\right]
$$

where TAG (in arbitrary units) is a function of the time in days $(D)$ from the beginning of the experiment, the time at the maximum $D_{\mathrm{tg}}$, i.e. at the reserves saturation point $(30-40 \%$ of the intermoult; Anger and Dawirs 1981), and the duration of the stage $D_{\max }$. The coefficients $\alpha$ and $\beta$ were estimated by nonlinear regression $\left(r^{2}=0.98\right)$ analysis (NLIN; SAS 1988).

The expression was used to generate hypothetical TAG profiles for the shrimp larvae based on the differences in the moult cycles observed during the rearing experiments (Table 3; for the Artemia-fed larvae):

$\begin{array}{ccc}\text { Diet } & \begin{array}{c}D_{\mathrm{tg}}(\mathrm{d}) \\ \text { increment }=0.3\end{array} & \begin{array}{c}D_{\max }(\mathrm{d}) \\ \text { increment }=\end{array} \\ \text { HD-A } & 3-3.9 & 10-12 \\ \text { HD-B } & 3.9-4.8 & 10-13 \\ \text { LD-A } & 5.1-6 & 13-16\end{array}$

Variability at the beginning and asynchronous larval development were further represented by lagging $D$ by $0.25 \mathrm{~d}$ up to $1 \mathrm{~d}(D+0.25, D+0.5, \ldots, D+1)$. Although the slightly slower growth of the HD-B larvae is reflected by the larger values of $D_{\mathrm{tg}}$, variability in growth rates, and its possible influence in the TAG content, is not considered in the model so that the outputs represent only the simplest cases. The extremes in
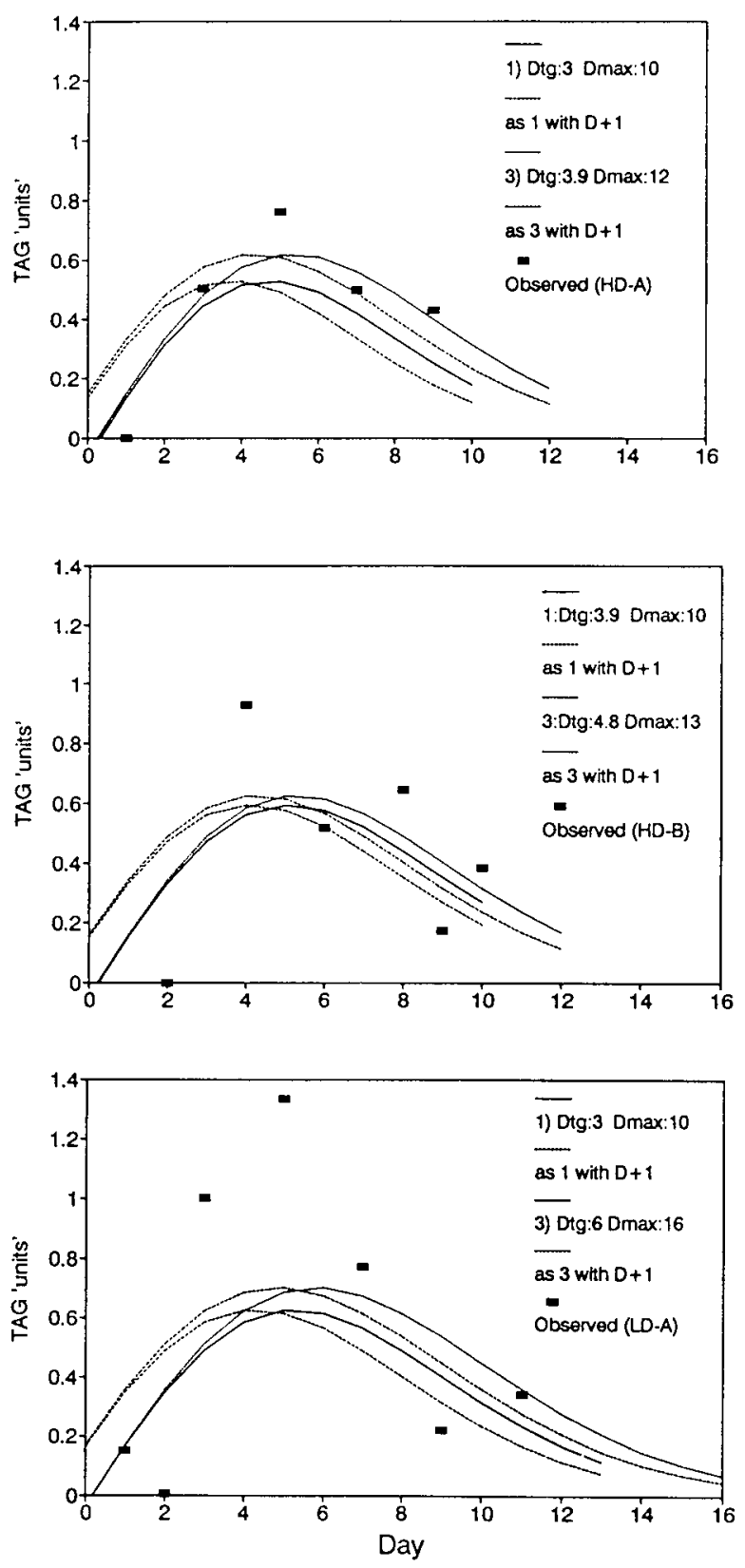

FIG. A.1. Simulated TAG cycles produced for each Artemia diet experiment with the corresponding daily mean $\mathrm{TAG} / \mathrm{WW}$ ratios observed during the first moult cycle for each treatment.

the simulated cycles corresponding to each experiment are provided (Fig. A.1) along with the measured daily mean TAG/ $W W$ values for the first moult cycle (from Fig. 4). Except for the high TAG/WW observed in LD-A, the measured TAG/WW ratios fit well in the limits of the simulated curves.

We further sampled (every second "day') mixtures of simulated curves prepared for each experiment and constructed frequency distributions of the data for comparison with the frequency distributions derived from the observations (Fig. A.2; to be compared with Fig. 5, top panel). Although the simulated data do not reproduce the range of dispersion observed in the measured TAG/WW ratios, the patterns are consistent with bimodal distributions and an increase in the proportion of val- 


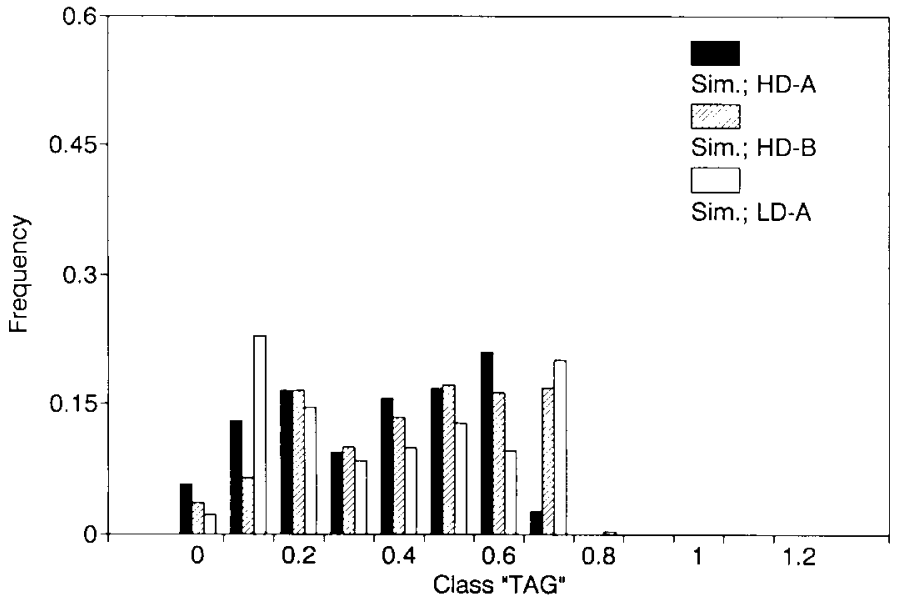

FIG. A.2. Frequency (relative) distribution generated by sampling mixtures of simulated cycles corresponding to each Artemia-fed larval group. ues in the lower classes intervals from HD-A to LD-A. Furthermore, a Kolmogorov-Smirnorv test revealed that, except for HD-B, there were no significant differences between the simulated and observed frequency distributions $(P>0.05)$. 